Mykhailo Mykhailov ${ }^{1}$

\title{
METHODOLOGICAL CONCEPT \\ OF THE RESEARCH OF CRIMINAL AND LEGAL SUPPORT AGAINST CORRUPTION BRIBERY IN UKRAINE
}

Keywords: corruption, bribery, illegal profit, corrupt bribery, criminal liability.

\begin{abstract}
The article presents the methodological concept of the study of criminal law support for combating corruption bribery in Ukraine. At the same time, the study of criminal liability for corruption bribery should be based on an appropriate methodological basis. Successful choice of methods of scientific knowledge has a direct impact not only on the research process but also on its results. To obtain reliable conclusions, it is unconditional to use the widest possible methodological tools, taking into account the peculiarities and specifics of the field of research.

The protection of human rights in Ukraine today is inextricably connected with combating such a negative phenomenon as corruption. This thesis is declared by a number of international legal agreements, laws and regulations of Ukraine. The European standards of combating corruption in the paradigm of the rule of law exactly allow to increase the effectiveness of the efforts of the Ukrainian society in this direction.

The above allows us to formulate a methodological concept for the study of criminal law support for combating corruption bribery in Ukraine.

Research of criminal liability for corruption bribery should be carried out from the standpoint of a binary approach:

1. To find out the cause and conditions of occurrence, as well as certain characteristics of the phenomenon itself - deviant behavior in the form of corrupt bribery.
\end{abstract}

1 Prosecutor of the Kyiv Local Prosecutor's Office № 1, Postgraduate Student at the Department of Criminal Law, Criminology and Judiciary, V.M. Koretsky Institute of State and Law of National Academy of Sciences of Ukraine, Mihailov0088@gmail.com. ORCID: 0000-0002-5448-5379. 
2. To develop the concept of criminal law counteraction to corruption bribery and development of substantiated scientific recommendations on the construction and content of relevant criminal law norms-prohibitions.

At the same time, the theory of social naturalism should be chosen as the primary source of worldviews for the study of criminal liability for corruption bribery. This will allow developing new concepts for the formation of law-abiding behavior in the anti-corruption sphere by reassessing the means of legal regulation, partial rejection of positivist principles and the introduction of natural - naturalistic approaches to the formation of criminal law.

\section{INTRODUCTION}

The protection of human rights in Ukraine today is inextricably connected with combating such a negative phenomenon as corruption. This thesis is declared by a number of international legal agreements, laws and regulations of Ukraine. In particular, the United Nations Convention against Corruption of $31^{\text {st }}$ October 2006, the Criminal Convention against Corruption (ETS 173) of $27^{\text {th }}$ January 1999, and the Civil Convention against Corruption of $4^{\text {th }}$ November 1999. The Inter-American Convention Against Corruption (IACAC) of 29 $9^{\text {th }}$ March 1996 and other international legal documents. The European standards of combating corruption in the paradigm of the rule of law exactly allow to increase the effectiveness of the efforts of the Ukrainian society in this direction.

Twinning the European worldview of the rule of law and combating corruption led to the approval of the State Program for the Implementation of the Principles of State Anti-Corruption Policy in Ukraine for 2015-2017. The information field is filled with calls to counteract corruption (combat it) inadmissible in a democratic society. Following the trends of social changes, the legal science also actualizes scientific research in this field.

In recent years, a number of acts of corruption have been criminalized, including bribery in various spheres of public life. These include bribery of officials in the field of public law (Articles 368, 369 of the Criminal Code of Ukraine), bribery of officials in the field of private law (Article 368-3 of the Criminal Code of Ukraine), bribery of persons providing public services (Article 368-4 of the Criminal Code of Ukraine), bribery 
of employees of enterprises, institutions and organizations that are not officials (Article 354 of the Criminal Code of Ukraine).

The criminalization of this range of activities involves the creation of a large number of commercial and other public and private organizations, including audit firms, private notaries, arbitration courts, private expert institutions, and others. Some representatives of these institutions are endowed with management functions, others are not. By abusing them, receiving illegal benefits, these individuals often harm the interests and authority of the service of these institutions, the rights of individuals, legal entities, the interests of society and the state. In this regard, the problem of criminal liability for corrupt bribery is becoming urgent in our country.

At the same time, the study of criminal liability for corruption bribery should be based on an appropriate methodological basis. Successful choice of methods of scientific knowledge has a direct impact not only on the research process but also on its results. To obtain reliable conclusions, it is unconditional to use the widest possible methodological tools, taking into account the peculiarities and specifics of the field of research.

\section{ANALYSIS OF RECENT RESEARCHES AND PUBLICATIONS}

Peculiarities of criminal and legal counteraction to corruption in Ukraine are the subject of researches of such scientists as P. Andrushko, M. Armanov, V. Berezner, O. Dudorov, V. Kyrychko, V. Kuts, D. Mykhailenko, A. Savchenko, V. Osadchiy, N. Yarmysh and others. At the monographic level, the legal measures to combat corruption were studied by V. Sukhonos. However, the description and study of the state of corruption crime needs to be constantly updated. The methodology of scientific knowledge in the criminal law sphere was covered in the researches of L. Demidova, O. Kostenko, M. Kostytskyi, M. Panov, P. Serdiuk, O. Kharytonov, T. Jatsyk and others. However, there have been made any developments in the methodology of criminal liability research for corruption. 
The purpose of publication - to highlight the methodological concept of the study of criminal law support for combating corruption bribery in Ukraine.

\section{PRESENTATION OF THE MAIN RESEARCH MATERIAL}

The methodology of the science of criminal law, like any science, is intended to ensure a high level of quality and efficiency of research in the relevant field of knowledge. The choice of methodology, which is the basis of scientific analysis, gives the research a fundamental character, indicates the basic worldview and philosophical as well as logical and epistemological principles that the researcher chooses as a means of scientific knowledge. It is well known that imperfections and shortcomings in the methodology and methods inevitably lead to possible errors and mistakes in the study and in the obtained results (Panov, 2018, p. 5).

A review of scientific researches in the field of criminal law allows us to state the fact that today there is no absolute unity in determining the range of techniques and methods of scientific research. Every scientist uses such methodological tools, which in his or her opinion should ensure the maximum effectiveness of the study. Herewith not only the number and types of selected methods differ, but also the understanding of research methodology and its structural elements. Recently, the use of so-called approaches instead of individual methods, which represent groups of methods used to study a particular issue, is becoming increasingly popular. The approach as a component of research methodology is proposed to understand a specific way of understanding the reality that arises, as a combination of fundamental ideas and certain methods, i.e. as a specific unity of worldview, theoretical and methodological knowledge, in which the main way is to combine theory and method (Serdiuk, 2010, p. 13).

Modern views on research methodology go beyond its understanding as a set of techniques and methods. In the doctrine, methodology is defined as an integral phenomenon that combines a number of components: worldview and fundamental general theoretical concepts, general 
philosophical laws and categories, general and specific scientific methods. Therefore, the methodology cannot be reduced to one of the named components, in particular to the method or the doctrine of methods, because in this case other components remain outside it (Kerymov, 2001, p. 46).

Sharing the above concept of understanding the methodology of cognition in the field of law, we should justify that scientific research in the cycle of criminal law is quite multifaceted, usually scientists use a variety of methods based on different methodological principles of cognition. There have been many attempts in jurisprudence to organize and systematize the methodology of cognition, but none of them has become dominant, which can be explained by the complexity and diversity of the object of study. After all, in the implementation of a specific scientific study, the choice of its methodology depends on the object of knowledge. It is the object of knowledge and is the decisive criterion that allows you to form general approaches to its study and determine specific approaches, methods, and worldviews that will provide the most reliable and balanced result.

Formation of the methodological basis in the study of criminal liability for corruption bribery is based on the position of academician M. Kostytskyi, who noted that when it comes to methodology in legal science, it is necessary to abandon the hierarchies of methodologies defined as philosophical, general scientific and specifically scientific. The methodologies should be "arranged" horizontally and used by a scientist of his choice. It can be jusnaturalistic, positivist, dialectical, synergetic or other methodology. It is not necessary to confuse oneself with methodology, it is possible to use methods from different methodologies, i.e. the methodology of a specific scientific research can look like a mosaic of methods. Methodology as a doctrine is necessary, first of all, for a scientist to develop a scientific worldview, which does not necessarily have to be an "orthodox" dialectic, jusnaturalist, positivist, synergetic, etc. (Kostytskyi, 2013, p. 10).

After all, in the implementation of a specific scientific study, the choice of its methodology depends on the object of knowledge. It is the object of knowledge and is the decisive criterion that allows you to form general approaches to its study and determine specific approaches, methods, and worldviews that will provide the most reliable and balanced result. 
M. Panov notes in this regard that the methodology of science has always been and is one of the central problems of the theory of cognition of objective reality, as it largely determines the ways and means of obtaining new and reliable knowledge. Extremely important role is played by methodology in legal science, and especially in the science of criminal law, which has a rather complex object of study - facts, phenomena of the objective world in the form of an indefinite set of acts of socially dangerous human behavior and orderly set (system) of criminal law norms designed to define and regulate these acts of conduct. Thus, this binary object is two interconnected systems of phenomena that are in organic unity and interaction: the first of them is the object (core) of the second, and the latter reflects, defines and legally fixes the elements of the first in all the variety of forms of their manifestation. In this regard, the development of problems' methodology, including methods and other cognitive procedures in research, is extremely important for in-depth knowledge of these systems and new and reliable (true) knowledge in the field of science and practice of criminal law (Panov, 2018, p. 14).

Defining the object of scientific research in the field of criminal law as a dichotomous phenomenon M. Panov points out that the first element of this structure belongs to the sphere of being (existing) - to the sphere of facts of social reality (acts of real socially dangerous behavior - specific actions of people, their socially dangerous actions); the second - to the sphere of the proper (in the reverse form - prohibitions of what should not be), which is reflected and enshrined in the rules of criminal law (Panov, 2017, p. 8-9).

This construction of the object of research determines the dual structure of the study process and the formation of two groups of techniques and methods, which will lead to more objective and reliable results. In our opinion, such an approach will allow us to fully explore both the existing - the facts of social reality, which require a criminal response, and the appropriate - legal requirements for compliance with certain rules of conduct, including criminal law norms-prohibitions.

Depending on which of these two system of phenomena is studied M. Panov identifies the most characteristic methods of scientific knowledge, which are used by scientists and provide the most balanced result. 
In particular, it is noticed that the study of the phenomena of the first element of the structure of the object of scientific knowledge - socially dangerous actions (deeds) of people - is carried out in several stages. In the first of them, the study of these objective phenomena is associated with the use of methods of observation, comparison, generalization, systematization, sociological measurement, statistical analysis, etc., which are often and conditionally called "empirical methods". Considering these objects are also used such methods and procedures of cognitive activity as induction and deduction, analysis and synthesis, experiment, idealization, analogy, etc. These techniques are used in the logical generalization and systematization of empirical data on these phenomena, clarifying their main features and typical forms of external manifestation, their prevalence, establishing social significance (social danger, harm) for human, citizen, state, society. At the second stage of scientific research are used general scientific methods of cognition, relevant laws and categories of dialectics, laws and rules of formal logic, means of formalization, differentiation and integration, abstraction, modeling, etc. Research and development of the second of elements of the structure of scientific object in criminal law, i.e. the system of criminal law and institutions, legal structures and other legal entities that make up the content of criminal law and legislation, is carried out using all the above general theoretical methods and cognitive procedures. At the same time, of course, widely used techniques and tools of criminal law (legislative technique) developed by the general theory of law and science of criminal law - various types of definitions (definitions), relevant linguistic techniques, common and special legal terms, typical methods of criminal law norms, legal constructions and other atypical normative prescriptions: presumptions, fictions, notes to articles of the Criminal code of Ukraine (Panov, 2018, p. 9-10).

This concept of determining the methodology of criminal law research is based on many years of experience in domestic legal science and, in our opinion, takes into account the most positive trends in the formation of the methodological basis. Of course, it is not unalterable, but its clarity and certainty in the formation and structuring of scientific research, defining its stages and directions allows to ensure the effectiveness and trans- 
parency of the study, the validity of the conclusions and a fairly high degree of reliability of the obtained results.

In our opinion, it is appropriate to investigate criminal liability for any antisocial behavior, including for committing corruption bribery, from the standpoint described by M. Panov binary approach, which will clarify the causes and conditions of occurrence, as well as certain characteristics of the phenomenon - deviant behavior, as well as provide an opportunity to develop a concept of criminal law counteraction and develop sound scientific advice on the construction and content of relevant criminal law norms-prohibitions.

First of all, a study of corruption bribery should be conducted as a phenomenon of objective reality, which requires counteraction by the state through criminal law influence. In particular, it is necessary to consider such issues as the historical and comparative principles of the study of criminal liability for corruption bribery, as well as the social conditionality of the criminalization of corruption bribery. It is advisable to use such methods as observation, comparison, generalization, systematization, sociological measurement, statistical analysis, comparative law as well as historical and law methods.

Secondly, the study should be devoted to regulatory criminal law support for combating corruption bribery. In particular, it is necessary to consider the objective and subjective features of the corpus delicti, which provide for criminal liability for corrupt bribery, punishment for corrupt bribery, release from punishment and serving it in the commission of this act, the application of other measures of criminal law and exemption from criminal responsibility. It is advisable to resort to the use of dialectical method, method of system analysis, formal and logical and others.

The choice of methodological tools of scientific knowledge will be incomplete without the formation of worldviews of the researcher, from which will be considered and analyzed this or that phenomenon. At the same time, without abandoning the achievements of dialectical, positivist and synergetic concepts, it is still worth noting a certain primacy of the scientific worldview, which will form the inviolable foundations of scientific research. Modern researchers of the methodology of scientific knowledge indicate the need for optimality and composition in the formation 
of research methodology. So L. Demydova in this regard, notes that the optimality and composition in the organization of the cognitive process is achieved by formulating and implementing a dominant idea, which is strategic and affects the choice of methodological tools and the limits of its use. The optimal compositional approach contributes to a comprehensive criminal law study and is reflected in the orderly structure of scientific work and its content (Demydova, 2015, p. 142).

To study the criminal responsibility for corruption bribery, we chose the concept of jusnaturalism as such a primary source of worldviews - the theory of social naturalism, the founder of which in Ukraine is O. Kostenko.

The scientist defines jusnaturalism methodology of all legal sciences, including criminal law and points out that based on the principle of natural integrity of the world, the principle of social naturalism can be formulated as follows: social phenomena should be considered as existing under the laws of nature as biological or physical phenomena. It means, in particular, that the will and consciousness are formed in people not in order to live outside the laws of nature, but, on the contrary, in order to live in harmony with them. Characterizing the heuristic possibilities of the principle of social naturalism in general, and in the philosophy of law in particular, it should be noted that it is suitable in order to use it to form a correct idea of the nature of various social phenomena. The drama of modern civilization is that among people there is a widespread misconception about the nature of things, which manifests itself in the form of arbitrariness and illusions. This is the basis of any social drama. As a result, it is lost the criterion for distinguishing between good and evil, truth and untruth, right and wrong, good and bad people, social norms and pathology, etc. O. Kostenko notes that the principle of social naturalism does not mean a transition to the path of reductionism (i.e., theoretical "lowering" of social phenomena from the highest stage of nature to the lower stages, which are biological and physical phenomena), in order to recognize the presence of social phenomena of natural foundations. It exists another way of recognizing the natural basis of social phenomena, namely: to recognize in accordance with the principle of social naturalism a common natural basis on which there are physical, biological and social phenomena 
- these are the laws of Mother Nature, which is a "common denominator" for all things (Kostenko, 2006-2007, p. 99-100).

Scientific research in the field of criminal liability for corruption bribery from the standpoint of social naturalism should provide a new impetus to the development of criminal law support to combat this phenomenon, provide an opportunity to develop new tools and methods of criminal law response to this type of social behavior, principles of human existence and assessment of existing criminal law norms for their compliance with the principles of social naturalism.

\section{CONCLUSIONS}

The above allows us to formulate a methodological concept for the study of criminal law support for combating corruption bribery in Ukraine.

Research of criminal liability for corruption bribery should be carried out from the standpoint of a binary approach:

1. To find out the cause and conditions of occurrence, as well as certain characteristics of the phenomenon itself - deviant behavior in the form of corrupt bribery.

2. To develop the concept of criminal law counteraction to corruption bribery and development of substantiated scientific recommendations on the construction and content of relevant criminal law norms-prohibitions.

At the same time, the theory of social naturalism should be chosen as the primary source of worldviews for the study of criminal liability for corruption bribery. This will allow developing new concepts for the formation of law-abiding behavior in the anti-corruption sphere by reassessing the means of legal regulation, partial rejection of positivist principles and the introduction of natural - naturalistic approaches to the formation of criminal law. 


\section{BIBLIOGRAPHY:}

Demydova, L. (2015). Kryminalne pravo v zahalnii systemi naukovykh znan: metodolohichnyi aspekt kryminalno-pravovykh doslidzhen [Criminal law in the general system of scientific knowledge: methodological aspect of criminal law research]. Yurydychnyi visnyk, no. 3 (36), pp. 139-143.

Kerymov, D. (2001). Metodolohyia prava (predmet, funktsyy, problemb fylosofyy prava) [Methodology of law (subject, functions, problems of philosophy of law)]. Moscow: Avanta. [in Russian]

Kostenko, O. (2006-2007.) Sotsialnyi naturalizm yak metodolohichnyi pryntsyp filosofii prava [Social naturalism as a methodological principle of philosophy of law]. Problemy filosofii prava, no. IV-V, pp. 98-106.

Kostytskyi, M. (2013). Deiaki pytannia metodolohii yurydychnoi nauky [Some questions of methodology of legal science]. Retrieved from: http://nbuv.gov.ua/UJRN/ Nvknuvs_2013_1_3.

Panov, M. (2017). Osnovy metodolohii nauky kryminalnoho prava [Fundamentals of the methodology of the science of criminal law]. Retrieved from: http://nbuv.gov.ua/ UJRN/vakpu_2017_2_3.

Panov, M. (2018). Problemy metodolohii nauky kryminalnoho prava: vybrani naukovi pratsi [Problems of the methodology of science of criminal law: selected scientific works]. Kharkiv: Pravo. [in Ukrainian]

Serdiuk, O. (2010). Sotsiolohichnyi pidkhid u suchasnomu pravoznavstvi: filososkopravove doslidzhennia [Sociological approach in modern jurisprudence: philosophical and legal researches]. (Dr.Sc. (Juridical) Thesis). Kharkiv: Yaroslav Mudryi National Law University. 